\title{
Identification, Characterization, and Developmental Regulation of Embryonic Benzodiazepine Binding Sites
}

\author{
Lawrence A. Borden, Terrell T. Gibbs, and David H. Farb \\ Department of Anatomy and Cell Biology, The State University of New York, Health Science Center at Brooklyn, Brooklyn, \\ New York 11203
}

\begin{abstract}
We report the identification and characterization of 2 classes of benzodiazepine binding sites in the embryonic chick CNS. Binding was examined by competition and saturation binding experiments, using as radioligands ${ }^{3} \mathrm{H}$-flunitrazepam, a classical benzodiazepine anxiolytic, and ${ }^{3} \mathrm{H}-\mathrm{R} 05-4864$, a convulsant benzodiazepine. The results demonstrate that highaffinity $\left(K_{D}=2.3 \mathrm{nM}\right.$ ) ${ }^{3} \mathrm{H}$-flunitrazepam binding sites (site-A) are present by embryonic day 5 (Hamburger and Hamilton stage 27) and increase throughout development $\left(B_{\max }=0.3\right.$ and $1.3 \mathrm{pmol} / \mathrm{mg}$ protein in 7 and $20 \mathrm{~d}$ brain membranes, respectively). When 7 or $20 \mathrm{~d}$ brain membranes are photoaffinity-labeled with ${ }^{3} \mathrm{H}$-flunitrazepam and ultraviolet light, the radioactivity migrates as 2 bands on SDS-PAGE, consistent with $M, s$ of 48,000 and 51,000 . GABA potentiates ${ }^{3} \mathrm{H}$ flunitrazepam binding at both 7 and $20 \mathrm{~d}$ of development, indicating that site-A is coupled to receptors for GABA early in development. Importantly, we have also identified a novel site (site-B) that binds classical benzodiazepine agonists with low affinity (micromolar) but displays high affinity for Ro5-4864 $\left(K_{b}=41 \mathrm{nM}\right)$. Site-B displays characteristics expected for a functional receptor, including stereospecificity and sensitivity to inactivation by heat and protease treatment. Saturation binding studies employing ${ }^{3} \mathrm{H}-\mathrm{Ro5-4864}$ indicate that the levels of site-B are similar in 7 and $20 \mathrm{~d}$ brain (ca. $2.5 \mathrm{pmol} / \mathrm{mg}$ protein). The function of site-B is not known, but its preponderance in $7 \mathrm{~d}$ brain, relative to site-A, suggests that it might be important during early embryonic development.
\end{abstract}

Dramatic changes in the number and distribution of neurotransmitter receptors and in the kinetics of neurotransmitter biosynthesis and degradation occur during embryonic development (Wilson et al., 1970; Burden, 1977; Cochard et al., 1978; Schuetze et al., 1978). Most developmental studies have examined classical neurotransmitter receptors such as $\mathrm{ACh}$ and GABA (Enna et al., 1976), which directly elicit a postsynaptic response. Benzodiazepines (BZDs) increase the potency of GABA through modulatory interactions, thereby enhancing GABA-in-

\footnotetext{
Received Oct. 1, 1986; accepted Dec. 23, 1986.

We would like to thank Cynthia Czajkowski for generously contributing the SDS gel experiment shown in Figure 9 and Dominic Roca for contributing the data shown in Figure 1. We also acknowledge the significant contributions of Richard Stafford, Arthur Kornbluth, and Gary Shifrin, who were supported by an NIH summer research fellowship 5 T35 HL 07493. T.T.G. was a recipient of a postdoctoral fellowship from the Muscular Dystrophy Association. This work was supported by NIH NS-18356 and a grant from New York Heart.

Correspondence should be addressed to Dr. David Farb, Department of Anatomy and Cell Biology, Box 5, The State University of New York, Health Science Center at Brooklyn, 450 Clarkson Avenue, Brooklyn, NY 11203.

Copyright (C) 1987 Society for Neuroscience $0270-6474 / 87 / 061902-09 \$ 02.00 / 0$
}

duced conductance increases (Choi et al., 1977, 1981; see Haefely and Polc, 1983, for review). Little is known of the development of receptors for neuromodulators such as the BZDs, and our initial report of multiple BZD binding sites in embryonic brain suggested that the expression of these sites might change during early development (Chan et al., 1983).

The presence of functional BZD receptors in cell cultures derived from early chick embryos [7 d of incubation, Hamburger and Hamilton (1951) stage 31] (Choi et al., 1977) suggests that BZD receptors and GABA receptors appear quite early in development. This hypothesis gains support from the observation that GABA and BZDs inhibit spontaneous motility in chick embryos after only $4 \mathrm{~d}$ of development (Reitzel et al., 1979; Maderdrut et al., 1983), but it is not known whether such effects are mediated by high-affinity binding sites. In the developing rat brain, BZD binding sites are first observed on gestational day 14 (Schlumpf et al., 1983), but it is not known whether these sites are functional receptors or drug acceptor sites. The early embryonic development of BZD receptors in the chick central nervous system has not been reported previously. Accordingly, we have examined the reversible and irreversible binding of ${ }^{3} \mathrm{H}$-flunitrazepam, a classical BZD anticonvulsant and tranquilizer, and the reversible binding of ${ }^{3} \mathrm{H}-\mathrm{Ro5}-4864$, a BZD convulsant, to membranes prepared from embryonic chick brain at various stages of development. We find that high-affinity ${ }^{3} \mathrm{H}$-flunitrazepam binding sites $\left(M_{r} \mathrm{~s}=48,100\right.$ and 51,000$)$ are present by embryonic day 5 (Hamburger and Hamilton stage 27 ) and increase in number throughout development. GABA enhances ${ }^{3} \mathrm{H}$-flunitrazepam binding to membranes derived from both 7 and 20 d embryos, indicating that coupling between BZDand GABA-receptors is present early in development. In addition, we have identified a novel embryonic site (site-B) that binds classical BZD agonists with low affinity but displays high affinity for Ro5-4864. Saturation binding studies using ${ }^{3} \mathrm{H}-\mathrm{Ro5}-$ 4864 demonstrate that site- $\mathrm{B}$ is present at stable levels in both early and late embryonic brain. The function(s) of site-B remains to be elucidated.

\section{Materials and Methods \\ Materials}

${ }^{3} \mathrm{H}$-flunitrazepam $(84 \mathrm{Ci} / \mathrm{mmol})$ and ${ }^{3} \mathrm{H}-\mathrm{Ro} 5-4864(81 \mathrm{Ci} / \mathrm{mmol})$ were obtained from New England Nuclear. Unlabeled BZDs were kindly provided by Hoffman-La Roche (Nutley, NJ). GABA and bicuculline were obtained from the Sigma Chemical Company, molecular-weight standards from BIO-RAD, and Liquiscint from National Diagnostics.

\section{Methods}

Tissue preparation. The $5 \mathrm{~d}$ [Hamburger and Hamilton (1951) stage 27], $7 \mathrm{~d}$ (stage 31), $10 \mathrm{~d}$ (stage 36), $12 \mathrm{~d}$ (stage 38), $15 \mathrm{~d}$ (stage 41), and $20 \mathrm{~d}$ (stage 45) embryonic chicks were decapitated and their brains removed, stripped free of meninges, and kept on ice in phosphate- 


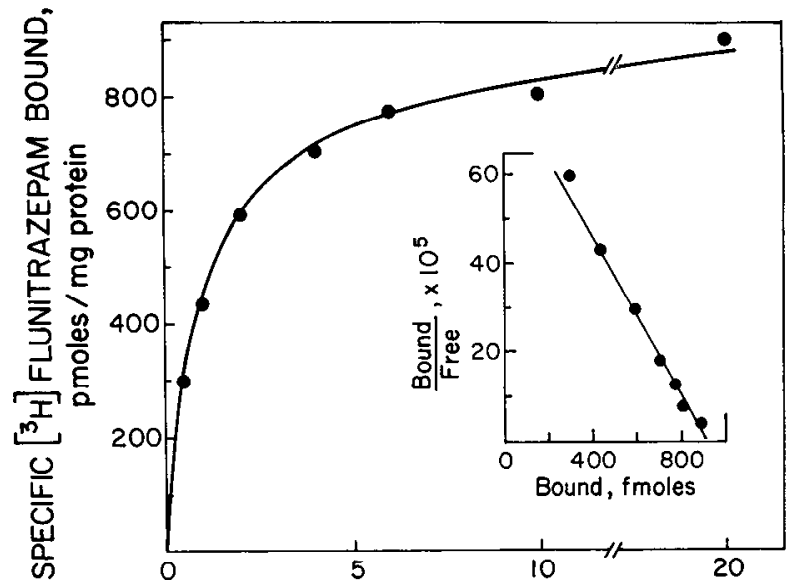

Figure 1. Saturation binding of ${ }^{3} \mathrm{H}$-flunitrazepam to $20 \mathrm{~d}$ embryonic brain membranes. The $20 \mathrm{~d} \mathbf{P}_{2}$ membranes were incubated with the indicated concentrations of ${ }^{3} \mathrm{H}$-flunitrazepam $\left(60 \mathrm{~min}, 0^{\circ} \mathrm{C}\right)$, and bound radioactivity was determined by filtration. Nonspecific binding, determined in the presence of $1 \mathrm{~mm}$ flurazepam, has been subtracted. Line shows computer-generated 1 -site fit to the data. Inset, Same data plotted hy the method of Scatchard. The parameters obtained were $K_{D}=1.1$ $\mathrm{nM} ; B_{\max }=917 \mathrm{fmol} / \mathrm{mg}$ protein.

buffered salt solution (PBSS: $123 \mathrm{~mm} \mathrm{NaCl}, 5.4 \mathrm{~mm} \mathrm{KCl}, 11 \mathrm{~mm} \mathrm{NaPO}_{4}$, $0.9 \mathrm{~mm} \mathrm{CaCl}_{2}, 0.4 \mathrm{~mm} \mathrm{MgSO}_{4}, 22.2 \mathrm{~mm}$ glucose, $\mathrm{pH}$ 7.4). Tissue was transferred to 10-20 volumes of $0.32 \mathrm{M}$ sucrose and homogenized in a close-fitting glass/Teflon homogenizer (10 strokes). The homogenate was centrifuged at $1000 \times g$ for $5 \mathrm{~min}$, and the supernatant was then centrifuged at $30,000 \times g$ for $20 \mathrm{~min}$. The resulting pellet $\left(\mathrm{P}_{2}\right)$ was homogenized in PBSS and frozen at $-70^{\circ} \mathrm{C}$. Tissue was later thawed, washed twice by centrifugation in PBSS, and refrozen. For G $\Lambda \mathrm{B} \Lambda$ enhancement studies, tissue was washed twice in PBSS and then twice in ice-cold water, followed by 2 more washes in PBSS; tissue was then refrozen.

Binding assays. Immediately before use in binding assays, tissue was thawed and suspended in the appropriate volume of ice-cold PBSS. Assay tubes containing ${ }^{3} \mathrm{H}$-flunitrazepam or ${ }^{3} \mathrm{H}-\mathrm{Ro5}-4864$ (and other drugs as required) in PBSS were chilled on ice, and incubations were started by the addition of $\mathrm{P}_{2}$ membranes; total incubation volume was $0.5 \mathrm{ml}$. For saturation experiments, the concentration of radioligand was varied. For competition experiments, assay tubes contained 1 concentration of ${ }^{3} \mathrm{H}$-flunitrazepam (generally 2 or $5 \mathrm{~nm}$ ) or ${ }^{3} \mathrm{H}-\mathrm{Ro} 5-4864$ (generally 1 or $2 \mathrm{nM}$ ) and various concentrations of unlabeled drug. Nonspecific binding was determined in the presence of $1 \mathrm{~mm}$ flurazepam (for ${ }^{3} \mathrm{H}$-flunitrazepam binding) or 2 mM flurazepam (for ${ }^{3} \mathrm{H}-\mathrm{Ro} 5-4864$ binding) and was subtracted from total binding (no competitor) to yield specific binding; similar values for nonspecific binding were obtained with other BZD competitors. All determinations were performed in at least triplicate. Incubations were continued on ice until equilibrium was reached (60 min for ${ }^{3} \mathrm{H}$-flunitrazepam, $90 \mathrm{~min}$ for $\left.{ }^{3} \mathrm{H}-\mathrm{Ro5}-4864\right)$ and terminated by the addition of $5 \mathrm{ml}$ ice-cold PBSS. Incubation mixtures were immediately poured over Whatman $\mathrm{GF} / \mathrm{B}$ glass fiber filters, filtered rapidly under vacuum, and washed 3 times with ice-cold PBSS $(5 \mathrm{ml}$ each). Filters were placed in scintillation vials, $5 \mathrm{ml}$ Liquiscint was added, and radioactivity was determined by liquid scintillation counting in a Packard Tricarb counter, model 4530 (counting efficiency, ca. 41\%)

Photoaffinity labeling. "Photoinactivation" of $\mathrm{P}_{2}$ homogenates was carried out as described previously (Gibbs et al., 1985). Membrane homogenates $(0.1-5 \mathrm{mg}$ protein $/ \mathrm{ml})$ were incubated with $100 \mathrm{~nm}$ flunitrazepam $\left(20 \mathrm{~min}, 4^{\circ} \mathrm{C}\right)$, then irradiated $20 \mathrm{~min}$ at a distance of $1-2 \mathrm{~cm}$ with a General Electric F40BLB blacklight bulb. Solution depth was less than $5 \mathrm{~mm}$ to minimize attenuation of ultraviolet light. Control membranes were treated identically except that they were not irradiated. Membranes were washed 4 times by centrifugation $(30,000 \times g, 20$ $\mathrm{min}$ ) and resuspension in $40-50 \mathrm{ml}$ PBSS, and then frozen at $-70^{\circ} \mathrm{C}$.

Photolabeling of $\mathrm{P}_{2}$ membranes was performed using a protocol identical to that for photoinactivation except that $5 \mathrm{nM}{ }^{3} \mathrm{H}$-flunitrazepam was employed. Some incubations contained $1 \mathrm{~mm}$ flurazepam to define nonspecific photolabeling.

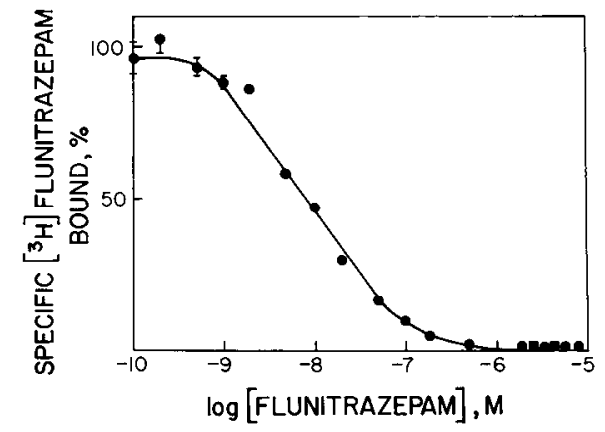

Figure 2. Dependence of ${ }^{3} \mathrm{H}$-flunitrazepam binding to $20 \mathrm{~d}$ membranes on competitor concentration. The $20 \mathrm{~d}$ brain membranes were incubated with $5 \mathrm{nM}{ }^{3} \mathrm{H}$-flunitrazepam and the indicated concentrations of unlabeled flunitrazepam $\left(0^{\circ} \mathrm{C}, 60 \mathrm{~min}\right)$. Nonspecific binding has been subtracted. Line shows computer-generated 1 -site fit to data $\left(K_{l}=3.9 \mathrm{nM}\right)$.

SDS gel electrophoresis. SDS-PAGE was performed according to the method of Laemmli (1970). Samples were boiled $3 \mathrm{~min}$ in buffer containing 0.625 м Tris- $\mathrm{HCl}$ (pH 6.8), 2\% SDS, $10 \%$ glycerol, 5\% 2-mercaptoethanol, and $0.001 \%$ bromophenol blue (tracking dye) before application to $10 \%$ polyacrylamide gels. The following proteins were used as molecular-weight $\left(M_{r}\right)$ standards: phosphorylase B $\left(M_{r}=92,000\right)$, BSA $\left(M_{r}=66,200\right)$, ovalbumin $\left(M_{r}=45,000\right)$, carbonic anhydrase $\left(M_{r}=\right.$ $31,000)$, soybean trypsin inhibitor $\left(M_{r}=21,500\right)$, and lysozyme $\left(M_{r}=\right.$ 14,400 ). Electrophoresis was at $20 \mathrm{~mA}$ for $6-8 \mathrm{hr}$. Following electrophoresis, gels were fixed and stained with $0.4 \%$ Coomassie Brilliant blue solution in $50 \%$ methanol $/ 7 \%$ acetic acid and destained in $7 \%$ acetic acid. Lanes were cut into $1 \mathrm{~mm}$ segments, the slices were dissolved overnight in $0.5 \mathrm{ml}$ hydrogen peroxide, and radioactivity was determined by scintillation counting.

Stock solutions. Chlordiazepoxide and flurazepam were made up in water or directly in PBSS. Other BZDs were dissolved in DMSO and then diluted into PBSS; the final concentration of dimethylsulfoxide (DMSO) was generally $0.05-0.5 \%$ and never exceeded $1 \%$. The concentration of solvent was kept constant within any experiment and control experiments demonstrated that DMSO in this concentration range affected specific binding by less than $5 \%$.

Control experiments suggested that Ro5-4864 precipitated from aqueous stock solutions. R05-4864 was dissolved in isopropanol, and the optical density was measured at 230 or $315 \mathrm{~nm}$ in a Bausch \& Lomb Spectronic 710 spectrophotometer using quartz cuvettes. The concentration of Ro5-4864 was calculated from the equation $C=A / E L$, where $C$ is concentration; $A$, absorbance; $E$, extinction coefficient $(34,100$ and 2390 at 230 and $315 \mathrm{~nm}$, respectively, both in isopropanol); and $L, 1$ $\mathrm{cm}$ path length (extinction coefficients kindly provided by $\mathrm{Dr}$. V. Toome, Hoffman-La Roche, Nutley, NJ). For binding studies, dilutions were made up from a stock solution $(1.23 \mathrm{~mm})$, and the concentration of isopropanol was kept constant in all assay tubes $(0.5 \%)$.

Data analysis. Data were analyzed by an Apple computer using a nonlinear regression program based on the "patternsearch" algorithm of Hooke and Jeeves (1961). Data were weighted according to the inverse of the variance from replicate determinations. Data were fitted to theoretical 1- and 2-site models, and the adjusted sums-of-squares were compared. The adjusted sum-of-squares was calculated from the equation $S_{\text {adj }}=S /(n-p)$, where $n$ is the number of experimental values and $p$ is the number of adjustable parameters ( 3 for the 1-site model, 5 for the 2-site model). For 2-site models, the binding to each site is reported as a percentage of the total binding. $K_{I}$ values were calculated from the equation $K_{I}=\mathrm{IC}_{50} /\left(1+L^{*} / K_{D}{ }^{*}\right)$ (Cheng and Prusoff, 1973), where $\mathrm{IC}_{50}$ is the concentration of competitor that inhibits $50 \%$ of the binding of radioligand, $L^{*}$ is the concentration of radioligand, and $K_{D}{ }^{*}$ is the dissociation constant of the radioligand.

\section{Results}

Equilibrium binding of ${ }^{3} \mathrm{H}$-flunitrazepam to membranes of 20 d embryos

The specific binding of ${ }^{3} \mathrm{H}$-flunitrazepam to $20 \mathrm{~d}$ membranes increased in a time-dependent manner, and equilibrium was 


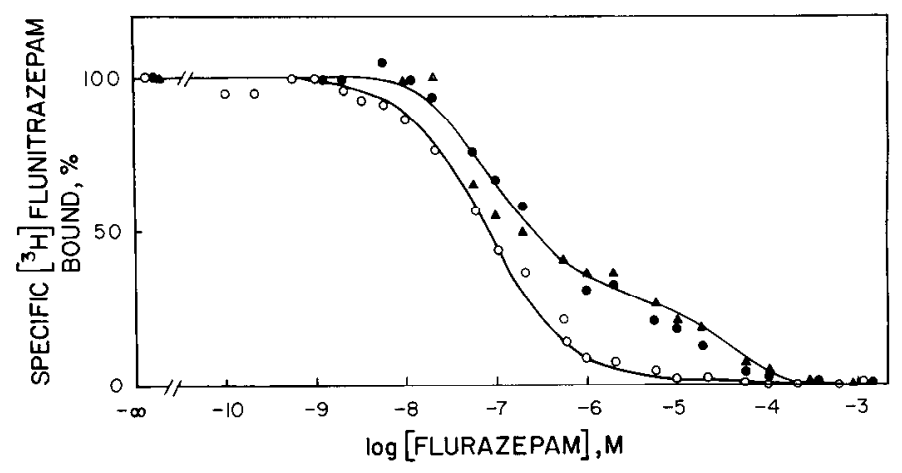

Figure 3. Displacement of ${ }^{3} \mathrm{H}$-flunitrazepam binding to early $(7 \mathrm{~d})$ and late $(20 \mathrm{~d})$ embryonic brain membranes reveals low-affinity binding. The $20 \mathrm{~d}(\mathrm{O})$ and $7 \mathrm{~d}$ ( and $\boldsymbol{\Delta}, 2$ experiments) chick brain membranes were incubated with $5 \mathrm{nM}{ }^{3} \mathrm{H}$-flunitrazepam and the indicated concentrations of flurazepam. Lines fitted by computer-generated 1 -site $(20 \mathrm{~d})$ or 2 -site $\left(7\right.$ d) competition curves. The $K_{t}$ values obtained were as follows: $20 \mathrm{~d}, 47 \mathrm{~nm} ; 7 \mathrm{~d}(\mathbf{\Lambda})$ : site-A, $53 \mathrm{~nm}$ (70\% of total binding); site-B, $20 \mu \mathrm{M}$. [Redrawn from Chan et al. (1983), by permission of publisher.]

reached by ca. $30 \mathrm{~min}\left(4^{\circ} \mathrm{C}\right)$; specific binding decreased upon dilution or the addition of competitor ( $1 \mathrm{~mm}$ flurazepam), indicating that binding was reversible. The equilibrium binding of ${ }^{3} \mathrm{H}$-flunitrazepam to $20 \mathrm{~d} \mathrm{P}_{2}$ membranes is shown in Figure 1. As the concentration of ${ }^{3} \mathrm{H}$-flunitrazepam was increased, nonspecific binding increased linearly, whereas specific binding saturated at higher concentrations. Scatchard analysis (Fig. 1, inset) yields a straight line consistent with binding to a single highaffinity site. The $K_{D}$ value obtained was $2.3 \pm 0.1 \mathrm{nM}$, and the receptor density $\left(B_{\max }\right)$ was $1.27 \pm 0.18 \mathrm{pmol} / \mathrm{mg}$ protein $(n=$ 5 experiments).

The $K_{I}$ 's for a series of BZDs were determincd by competition experiments employing $20 \mathrm{~d} \mathrm{P}_{2}$ membranes. Membrane aliquots were incubated with ${ }^{3} \mathrm{H}$-flunitrazepam and various concentrations of unlabeled drug until equilibrium was reached. Figure 2 shows the results of a representative experiment in which flunitrazepam was used as competitor. As the concentration of flunitrazepam was increased, a progressive decrease of bound radioactivity was observed. The shape of the curve was consistent with binding to a single site. The $K_{I}$ value was $2.6 \pm 0.5 \mathrm{~nm}$ $(n=5)$, similar to the value of $2.3 \pm 0.1$ obtained from saturation binding. Table 1 shows the $K_{I}$ values for a number of
BZDs as determincd from competition experiments similar to that shown in Figure 2. Equilibrium binding was also measured at $37^{\circ} \mathrm{C}$. The $K_{I}$ for flurazepam $(210 \mathrm{~nm}$, mean of 2 experiments) was decreased approximately 5 -fold as compared to values obtained at $0^{\circ} \mathrm{C}$, in general agreement with results obtained with rat brain homogenates (Speth et al., 1979).

\section{Equilibrium binding to membranes from 7 d embryonic brain}

Competition experiments performed with $7 \mathrm{~d}$ membranes resulted in flattened or nonsigmoidal displacement curves. A representative experiment in which flurazepam was used as competitor is shown in Figure 3. Hill analysis yielded a straight line with a slope of 0.6 , inconsistent with Michaelis-Menten binding to a single site. When analyzed by nonlinear regression, the displacement data were well described by a 2-site model in which about $70 \%$ of the specific binding was to a high-affinity site (site-A, $K_{I}=40 \mathrm{~nm}$ for flurazepam) and $30 \%$ was to a loweraffinity site (site-B, $K_{I}=20 \mu \mathrm{M}$ ). The small size of $5 \mathrm{~d}$ embryonic brain precluded detailed experiments, but the results were similar to those obtained with $7 \mathrm{~d}$ brain membranes, consistent with the presence of multiple binding sites.

As ${ }^{3} \mathrm{H}$-flunitrazepam was the radioligand employed in these studies, it was important to determine if flunitrazepam bound with different affinities to the 2 sites. Competition experiments using unlabeled flunitrazepam indicated that flunitrazepam binds with high and low affinity to site-A and site-B, respectively. Clonazepam, flunitrazepam, diazepam, flurazepam, and chlordiazepoxide bound to $7 \mathrm{~d}$ membranes with both high and low affinities (Table 1), and the ratio of high- to low-affinity binding was similar for the different ligands. The results from all experiments on these 5 BZDs suggest that at $5 \mathrm{nM}{ }^{3} \mathrm{H}$-flunitrazepam, $21.7 \pm 2.9 \%(n=12)$ of the specific binding was to a distinct class of low-affinity sites. The $B_{\max }$ for site-A, extrapolated from competition curves, was $0.316 \pm 0.06 \mathrm{pmol} / \mathrm{mg}$ protein $(n=6)$. The ability to detect site- $\mathrm{B}$ with ${ }^{3} \mathrm{H}$-flunitrazepam, despite its low affinity, suggested that the site must be present in great abundance relative to site- $A$; the number of low-affinity sites present in embryonic brain will be discussed below (see section on binding of ${ }^{3} \mathrm{H}-\mathrm{Ro5}-4864$ ). Binding to $7 \mathrm{~d}$ membranes was also measured at $37^{\circ} \mathrm{C}$. Binding to site-B was detectable at this temperature, although the affinity of flunitrazepam (determined from competition experiments) was about 4-fold lower than at $0^{\circ} \mathrm{C}$.

Table 1. Binding affinities for embryonic BZD binding sites

\begin{tabular}{|c|c|c|c|c|}
\hline \multirow[b]{2}{*}{ BZD } & \multicolumn{2}{|c|}{${ }^{3} \mathrm{H}$-flunitrazepam binding sites ${ }^{a}$ (nM) } & \multirow{2}{*}{$\begin{array}{l}{ }^{3} \mathrm{H}-\mathrm{Ro} 5-4864 \\
\text { binding site } \\
\text { (nM) }\end{array}$} & \multirow{2}{*}{$\begin{array}{l}\text { "Peripheral" } \\
\text { sitec (nM) }\end{array}$} \\
\hline & Site-A & Site-B & & \\
\hline Clonazepam & $3.0 \pm 0.3(3)$ & $6400 \pm 2600$ & $7500 \pm 1700(3)$ & 6400 \\
\hline Flunitrazepam & $6.0 \pm 1.2(16)$ & $1430 \pm 310$ & $480 \pm 270$ & 17 \\
\hline Diazepam & $10.2 \pm 0.3(2)$ & $910 \pm 120$ & $660 \pm 320$ & 16 \\
\hline Flurazepam & $46.0 \pm 16(4)$ & $19,700 \pm 5300$ & $27,400 \pm 6000(3)$ & \\
\hline Chlordiazepoxide & $487 \pm 40(3)$ & $59,000 \pm 16,600(2)$ & $32,300 \pm 8000(3)$ & $>10,000$ \\
\hline Ro5-4864 & $>2000$ & $40 \pm 1$ & $9.9 \pm 0.7$ & 0.67 \\
\hline
\end{tabular}

Data shown $K_{I}$ values determined from competition binding experiments. Results are expressed as means \pm SEM (values in parentheses indicate number of determinations).

" Data derived from competition studies employing $20 \mathrm{~d}$ (site-A) and 7, 10, 12, and $15 \mathrm{~d}$ (site-A and site-B) embryonic chick brain membranes.

${ }^{b}$ Data derived from competition binding studies employing $7 \mathrm{~d}$ brain membranes.

c Data from Schoemaker et al. (1983) for adult rat brain. 

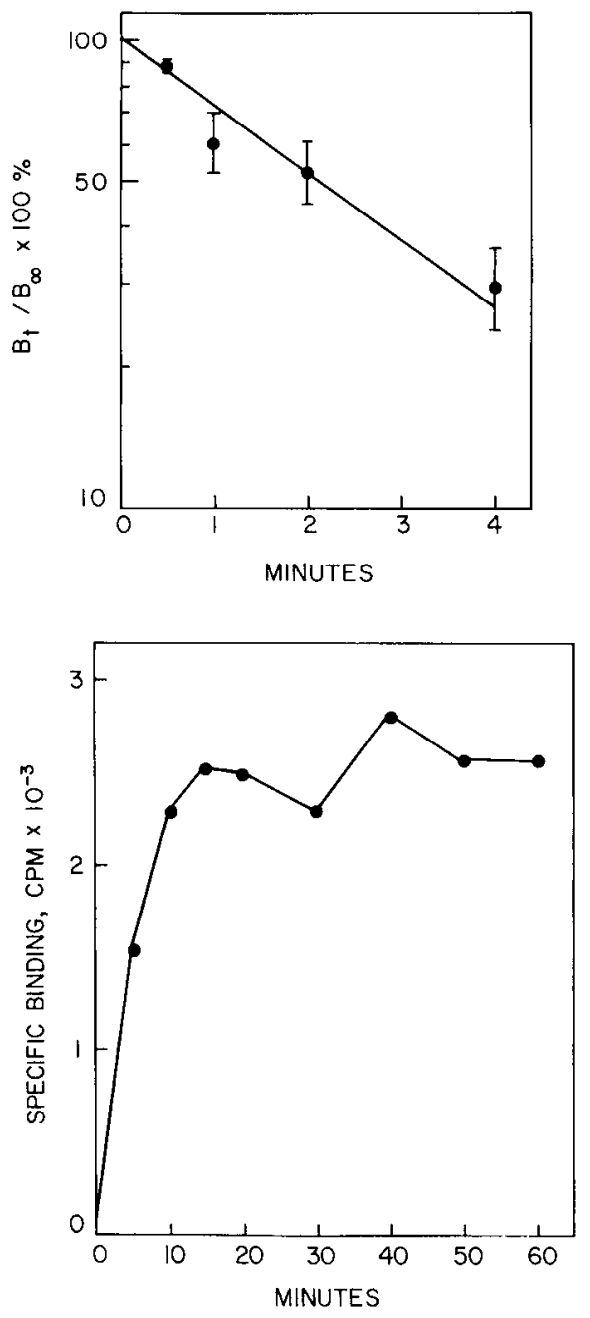

Figure 4. Kinetics of dissociation and association for ${ }^{3} \mathrm{H}$-flunitrazepam are consistent with low-affinity binding to $7 \mathrm{~d}$ brain. Top. Dissociation from site-B. The $7 \mathrm{~d}$ brain membranes were incubated with $58 \mathrm{~nm}{ }^{3} \mathrm{H}-$ flunitrazepam containing $1 \mu \mathrm{M}$ unlabeled flunitrazepam, with and without $1 \mathrm{~mm}$ flurazepam. After $30 \mathrm{~min}$, a small aliquot of flurazepam was added to give a final concentration of $1 \mathrm{~mm}$. Samples were filtered at the indicated times thereafter. Data show decrease in specific binding fit by computer analysis $\left(t_{1 / 2}=2.1 \mathrm{~min}\right)$. Bottom, Binding of ${ }^{3} \mathrm{H}$-flunitrazepam $\left(7.8 \mathrm{nM}, 0^{\circ} \mathrm{C}\right)$ to $7 \mathrm{~d}$ brain membranes approaches equilibrium within $30 \mathrm{~min}$.

High-affinity BZD binding to rat brain homogenates is modulated by chloride ions (Costa et al., 1979). As our standard buffer (PBSS) contains $0.4 \mathrm{mM} \mathrm{Cl}^{-}$, competition binding experiments (using unlabeled flurazepam) were also conducted in chloride-free Tris-acetate buffer ( $50 \mathrm{~mm}, \mathrm{pH}$ 7.4). The affinities and proportions of site-A and site-B were similar to those obtained with PBSS.

\section{Kinetics of ${ }^{3} \mathrm{H}$-flunitrazepam binding to $7 \mathrm{~d}$ membranes}

In the experiments described above, bound radioactivity was separated from free by a filtration assay in which the wash time was $10 \mathrm{sec}$. To determine how much bound radioactivity was lost during washing, membranes were incubated with $58 \mathrm{nM}{ }^{3} \mathrm{H}$ flunitrazepam and $1 \mu \mathrm{M}$ unlabeled flunitrazepam. Under these conditions $>90 \%$ of the specific binding of ${ }^{3} \mathrm{H}$-flunitrazepam was to site-B. Incubation was continued for $45 \mathrm{~min}$, sufficient for attainment of equilibrium, then $1 \mathrm{~mm}$ flurazepam (final con-
Table 2. Trypsin sensitivity of embryonic BZD binding sites

\begin{tabular}{|c|c|c|c|}
\hline \multirow{2}{*}{$\begin{array}{l}\text { Experi- } \\
\text { mental } \\
\text { condi- } \\
\text { tions }\end{array}$} & \multicolumn{2}{|c|}{$\begin{array}{l}{ }^{3} \mathrm{H} \text {-flunitrazepam binding sites } \\
(\% \text { control })\end{array}$} & \multirow{2}{*}{$\begin{array}{l}{ }^{3} \mathrm{H}-\mathrm{Ro} 5-4864 \\
\text { binding sites } \\
\text { (\% control) }\end{array}$} \\
\hline & Site- $A^{a}$ & Site-B ${ }^{b}$ & \\
\hline \multicolumn{4}{|c|}{ Trypsin $(\mathrm{mg} / \mathrm{ml})$} \\
\hline 5 & $13.6 \pm 0.4$ & $19.6 \pm 3.8$ & N.D. \\
\hline 1 & N.D. & $28.9 \pm 3.9$ & $25.3 \pm 5.9$ \\
\hline
\end{tabular}

Brain membranes $(7 \mathrm{~d})$ were incubated in the presence or absence of trypsin (90) min, $37^{\circ} \mathrm{C}$ ). Data show specific reversible binding (means $\pm \mathrm{SEM}$ ), expressed as a percentage of control binding (no trypsin). Tris- $\mathrm{HCl}$ (pH 7.4) was used for incubation and binding. N.D., not determined.

a Determined with $6.5 \mathrm{~nm}\left[{ }^{3} \mathrm{H}\right]$ flunitrazepam.

${ }^{\circ}$ Determined with $65 \mathrm{~nm}\left[{ }^{3} \mathrm{H}\right]$ flunitrazepam $+1 \mu \mathrm{M}$ unlabeled flunitrazepam.

' Determined with 2 nм [3 $\mathrm{H}] \mathrm{R} 05-4864$.

centration) was added. After various times, samples were poured over filters and washed as described in Materials and Methods. Dissociation of ${ }^{3} \mathrm{H}$-flunitrazepam from site-B was slow and firstorder (Fig. 4, bottom), exhibiting a half-time of about $2 \mathrm{~min}$ and a $k_{\text {off }}$ of $0.33 \mathrm{~min}^{-1} \cdot k_{\text {on }}\left(=k_{\text {nff }} / K_{n}\right)$ is thus equal to $2.05 \times$ $10^{5} \mathrm{M}^{-1} \mathrm{~min}^{-1}$, assuming a simple bimolecular reaction mechanism, yielding a half-time for association of ca. 2 min at $5 \mathrm{~nm}$ flunitrazepam. This is consistent with the observation that binding of $5 \mathrm{~nm}{ }^{3} \mathrm{H}$-flunitrazepam reached equilibrium after about $20 \mathrm{~min}$ (Fig. 4, bottom).

\section{Characterization of high-and low-affinity binding sites}

For further characterization of the embryonic BZD binding sites, the stereospecificity of high- and low-affinity binding sites and their sensitivity to heat and proteolytic enzymes were examined. The stereospecificity of binding to both site-A and site-B was examined by comparing the potencies of the pharmacologically active dextrorotatory BZD Ro11-6896 [B1O(+)] with the inactive levorotatory isomer Ro11-6893 [B10(-)] as inhibitors of ${ }^{3} \mathrm{H}$-flunitrazepam binding.

To examine the binding to site- $\mathrm{A}$ in $7 \mathrm{~d}$ membranes, $2 \mathrm{nM}$ ${ }^{3} \mathrm{H}$-flunitrazepam was used; under these conditions, $>90 \%$ of the specific binding was to site-A. At $1 \mu \mathrm{M}, \mathrm{B} 10(+)$ inhibited $95 \pm 0.6 \%$ of the specific binding, whereas B10(-) inhibited only $21 \pm 1 \%$. The stereospecificity of site-B was determined as follows: $7 \mathrm{~d}$ membranes were incubated with $65 \mathrm{~nm}{ }^{3} \mathrm{H}$ flunitrazepam and $1 \mu \mathrm{M}$ unlabeled flunitrazepam. At these concentrations, $>90 \%$ of the specific binding was to site- $\mathrm{B}$, and $\mathrm{B} 10(+)$ was a more potent competitor than $\mathrm{B} 10(-)$; for ex-

Table 3. GABA enhances ${ }^{3} \mathrm{H}$-flunitrazepam binding in both early and late embryonic brain

\begin{tabular}{cll} 
& \multicolumn{2}{l}{ Percentage of control } \\
\cline { 2 - 3 } Membrane & GABA & $\begin{array}{l}\text { GABA }+ \\
\text { bicuculline }\end{array}$ \\
\hline $7 \mathrm{~d}^{a}$ & $158 \pm 7$ & $115 \pm 1$ \\
$20 \mathrm{~d}^{b}$ & $182 \pm 14$ & $115 \pm 8$
\end{tabular}

Extensively washed 20 and $7 \mathrm{~d}$ brain membranes were incubated with ${ }^{3} \mathrm{H}$ flunitrazepam in the absence or presence of GABA or GABA and bicuculline. Results show specific binding expressed as percentage of control binding (no GABA added; means \pm SEM, triplicate determinations). This experiment was repeated with similar results.

${ }^{a}$ [GABA], $200 \mu \mathrm{M}$; [bicuculline], $100 \mu \mathrm{M}$; ${ }^{3} \mathrm{H}$-Hunitrazepam, $0.37 \mathrm{~nm}$.

${ }^{b}$ [GABA], $50 \mu \mathrm{M}$; [bicuculline], $500 \mu \mathrm{M} ;{ }^{3} \mathrm{H}$-flunitrazepam, $0.14 \mathrm{nM}$. 


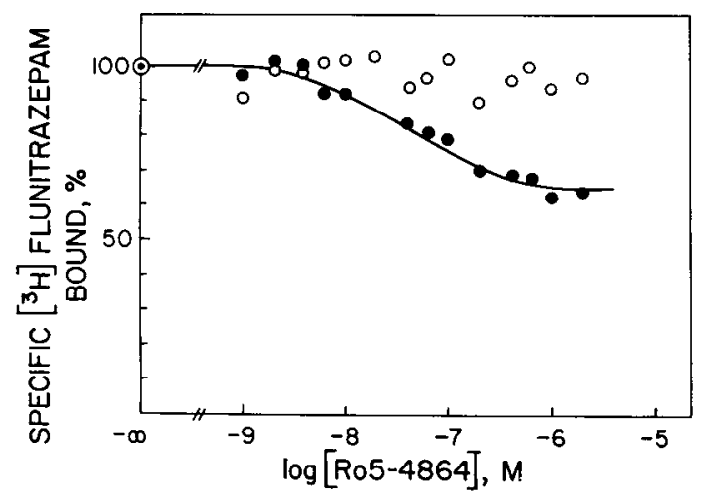

Figure 5. Ro5-4864 displaces, with high affinity, ${ }^{3} \mathrm{H}-$ flunitrazepam binding to site-B in early embryonic brain membranes. The $7 \mathrm{~d}(\bullet)$ and $20 \mathrm{~d}(\mathrm{O})$ brain membranes were incubated with $6 \mathrm{nM}{ }^{3} \mathrm{H}$-flunitrazepam in the presence of $\mathrm{Ro} 5-4864\left(0^{\circ} \mathrm{C}, 30 \mathrm{~min}\right)$ and filtered. Line is computergenerated 1 -site fit to specific binding data.

ample, at $60 \mu \mathrm{M}, \mathrm{B} 10(+)$ displaced $100 \pm 5 \%$ of specific binding, whereas $\mathrm{B} 10(-)$ displaced only $49 \pm 5 \%$.

High-affinity binding was eliminated when membranes were heated $\left(100^{\circ} \mathrm{C}, 90 \mathrm{~min}\right)$. Although low-affinity binding was still detected after heating, the binding no longer displayed the stereospecificity observed with control membranes. For example, following heating, $60 \mu \mathrm{M} \mathrm{B10}(+)$ and $\mathrm{B} 10(-)$ displaced $74 \pm$ 11 and $76 \pm 11 \%$ of specific binding, respectively. Additionally, binding to site-A and to site-B was decreased approximately $75 \%$ by trypsin (Table 2 ). Thus, both the high- and low-affinity binding sites displayed the stereospecificity and heat- and protease-sensitivity expected of functional BZD receptors.

To determine if GABA enhances BZD binding to embryonic chick brain, membranes were washed extensively to remove endogenous GABA (see Materials and Methods), and then the binding of ${ }^{3} \mathrm{H}$-flunitrazepam was measured in the absence and presence of added GABA. Table 3 shows that GABA increased specific binding $58 \%$ over control values in $7 \mathrm{~d}$ membranes, and this effect was blocked by the GABA-receptor antagonist bicuculline $(100 \mu \mathrm{M})$; similar results were obtained in $20 \mathrm{~d}$ brain membranes.

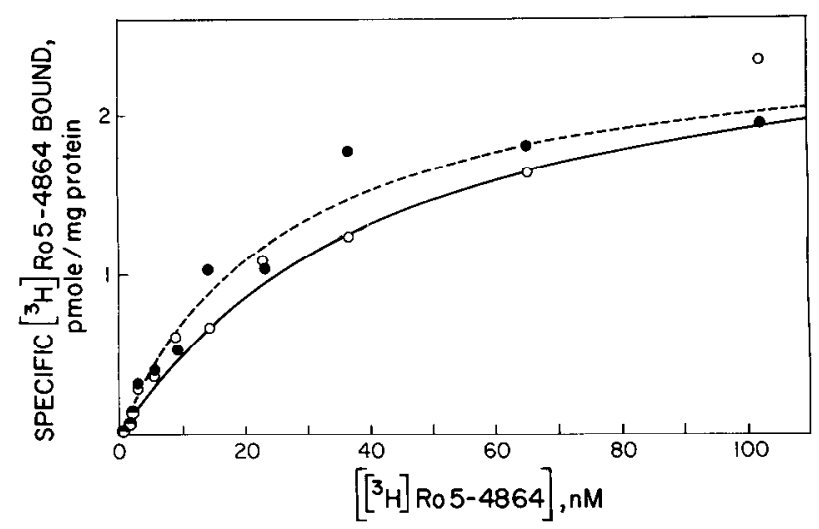

Figure 6. Saturation binding of ${ }^{3} \mathrm{H}-\mathrm{R} 05-4864$ to 7 and $20 \mathrm{~d}$ embryonic brain membranes reveals a similar number of sites at both ages. The 7 $\mathrm{d}(\mathrm{O})$ or $20 \mathrm{~d}(\mathbf{0})$ embryonic brain membranes were incubated with the indicated concentration of ${ }^{3} \mathrm{H}-\mathrm{Ro5}-4864$ and filtered. Nonspecific binding, determined in the presence of $2 \mathrm{~mm}$ flurazepam, has been subtracted. Data show means of a single experiment that was repeated with similar results.

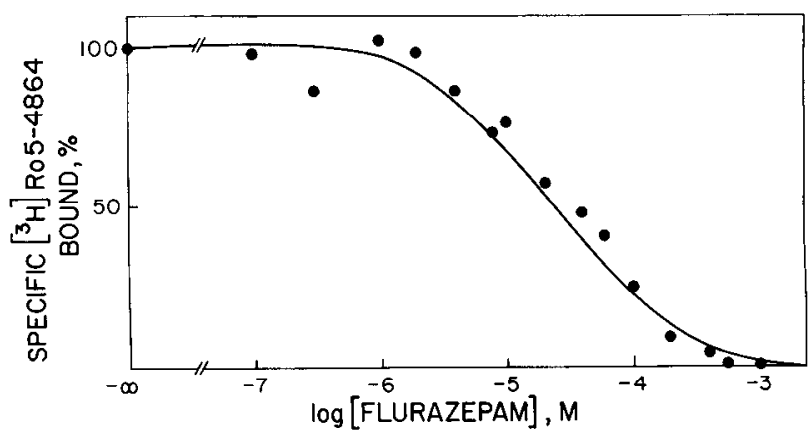

Figure 7. Flurazepam inhibits with low affinity the binding of ${ }^{3} \mathrm{H}-\mathrm{Ro} 5$ 4864 to $7 \mathrm{~d}$ brain membranes. The $7 \mathrm{~d}$ brain membranes were incubated with $1 \mathrm{nM}{ }^{3} \mathrm{H}-\mathrm{Ro5}-4864$ and the indicated concentration of flurazepam and were then filtered. Data points represent specific binding; line is computer-generated 1 -site fit of the data.

\section{"Central" versus "peripheral" sites}

In addition to the binding sites present in the brain, high-affinity BZD binding sites have also been observed in various peripheral (i.e., non-neural) tissues such as kidney (Braestrup and Squires, 1977; Regan et al., 1981). The brain type, or "central," and kidney type, or "peripheral," binding sites can be distinguished pharmacologically: the central site displays high affinity for flurazepam and clonazepam but low affinity for Ro5-4864 (a convulsant BZD), whereas the reverse relationship is observed for the peripheral site. Interestingly, BZD binding sites with high affinity for Ro5-4864 have also been observed in cell cultures of both neural (Syapin and Skolnick, 1979; Walker and Peacock, 1981; Sher, 1985) and non-neural (Matthew et al., 1981; Beaumont et al., 1984; Wang et al., 1984) origin. To characterize embryonic BZD binding sites, we compared the relative potencies of flurazepam and Ro5-4864 as inhibitors of ${ }^{3} \mathrm{H}$-flunitrazepam binding, using membranes derived from 7 and $20 \mathrm{~d}$ embryonic chick brain and adult rat brain. ${ }^{3} \mathrm{H}$-flunitrazepam binding to $20 \mathrm{~d}$ membranes was more sensitive to displaccment by flurazcpam than by Ro5-4864 (comparc Figs. 3 and 5), similar to results obtained with adult rat brain (not shown).

In $7 \mathrm{~d}$ brain membranes, however, Ro5-4864 displaced with high affinity $\left(K_{I}=40 \mathrm{nM}, n=2\right)$ about $30 \%$ of the specifically bound ${ }^{3} \mathrm{H}$-flunitrazepam (Fig. 5). Flurazepam displaced about $30 \%$ of the specific binding with low affinity (Fig. 3). These

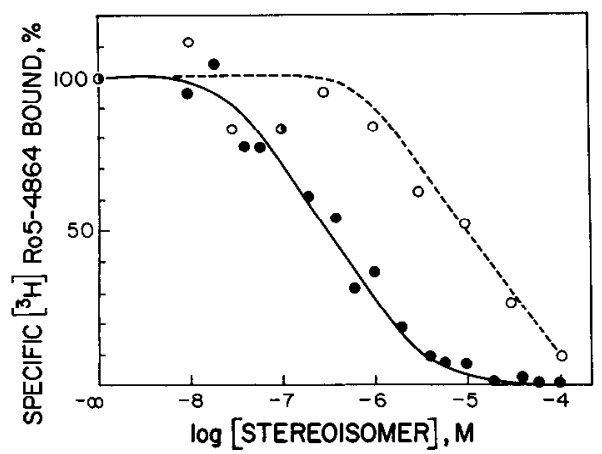

Figure 8. Binding of ${ }^{3} \mathrm{H}-\mathrm{Ro5}-4864$ to site-B displays stereospecificity. The $7 \mathrm{~d}$ brain membranes were incubated with $1 \mathrm{~nm}{ }^{3} \mathrm{H}-\mathrm{R} 05-4864$ and the indicated concentrations of $\mathrm{B} 10(+)(0)$ or $\mathrm{B} 10(-)(0)$ and were then filtered. Data represent specific binding; the lines are computer-generated 1 -site fits to the data. 


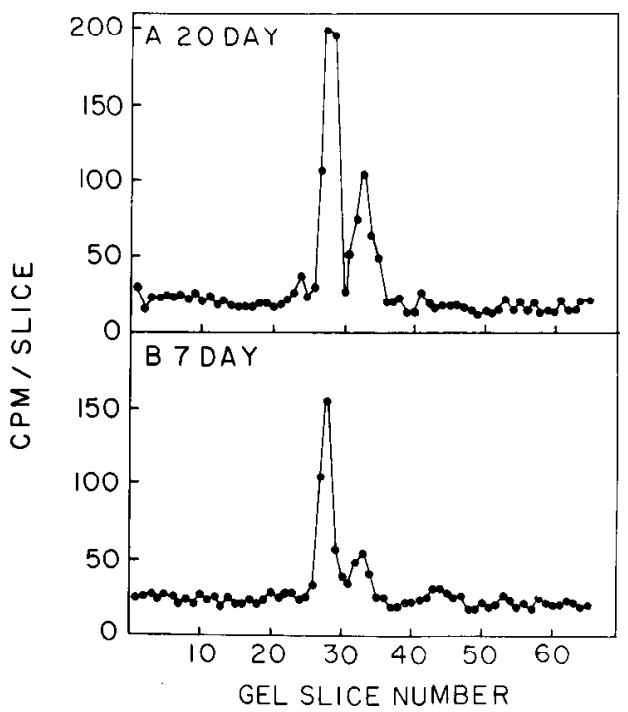

Figure 9. Photoaffinity labeling of early and late embryonic BZD binding sites with ${ }^{3} \mathrm{H}$-flunitrazepam. The $20 \mathrm{~d}(A)$ and $7 \mathrm{~d}(B)$ brain membranes were photolabeled with $5 \mathrm{~nm}{ }^{3} \mathrm{H}$-flunitrazepam as described in Materials and Methods and subjected to SDS-PAGE; radioactivity was determined in slices of individual gel lanes. The fractions of specific radioactivity recovered in the $M,=48,000$ peak $[37 \pm 2 \%(n=4), 7$ d; $37 \pm 2 \%(n=5), 20 \mathrm{~d}]$ and $M_{r}=51,000$ peak [63 $\pm 2 \%(n=4), 7$ d; $63 \pm 2 \%(n=5), 20 \mathrm{~d}]$ did not change with age.

results suggested that Ro5-4864 bound with high affinity to site-B. This hypothesis was supported by the finding that, under conditions where approximately $90 \%$ of the binding was to site-B (50 nм ${ }^{3} \mathrm{H}$-flunitrazepam $+1 \mu \mathrm{M}$ unlabeled flunitrazepam), 2 $\mu \mathrm{M}$ Ro5-4864 was able to displace $92 \pm 6 \%$ of the specific binding $(n=4)$. Thus, Ro5-4864 binds with high affinity to site-B, the site to which flurazepam, flunitrazepam, clonazepam, diazepam, and chlordiazepoxide bind with low affinity.

\section{Binding of ${ }^{3} \mathrm{H}-\mathrm{Ro} 5-4864$ to embryonic brain membranes}

The observation that Ro5-4864 displaced with high affinity the binding of ${ }^{3} \mathrm{H}$-flunitrazepam to site-B suggested that ${ }^{3} \mathrm{H}-\mathrm{Ro} 5$ -

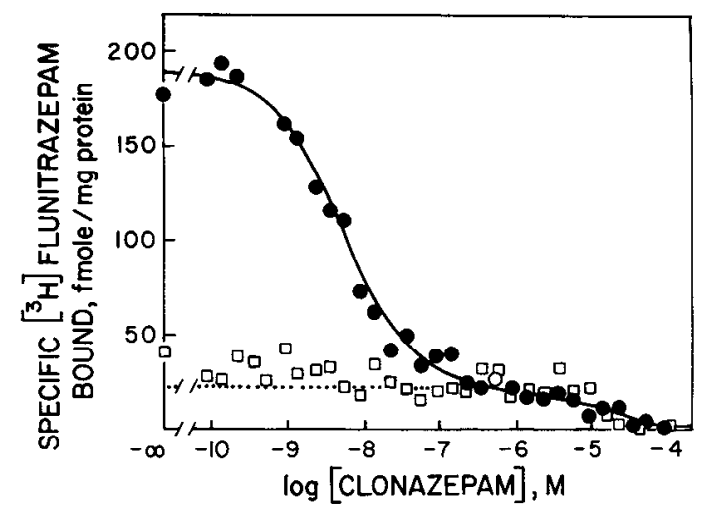

Figure 10. Photoinactivation of $7 \mathrm{~d}$ brain membranes spares site-B. The $7 \mathrm{~d}$ membranes were photoinactivated with $100 \mathrm{~nm}$ flunitrazepam as described in Materials and Methods ( $\square$ ); control membranes were incubated with flunitrazepam but not irradiated (๑). Membranes were washed and incubated with $2 \mathrm{nM}^{3} \mathrm{H}$-flunitrazepam and increasing concentrations of clonazepam. Nonspecific binding was determined with $100 \mu \mathrm{M}$ clonazepam. Data show specific binding; lines are computergenerated best 2-site fit for control membranes, 1-site fit for photoinactivated membranes. [Redrawn from Farb et al. (1985) Ann. NY Acad. Sci., vol. 435 , by permission of publisher.]

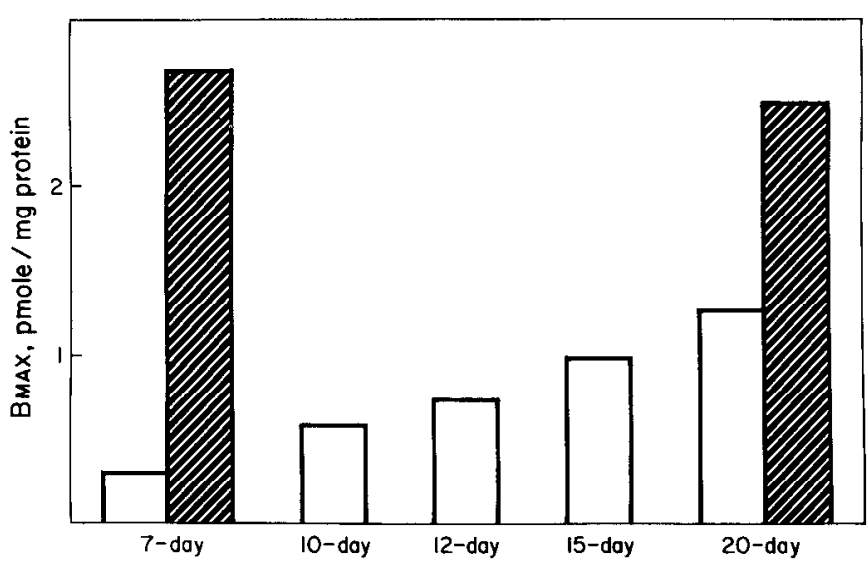

Figure 11. Site-A increases but site-B remains constant during embryonic development. $B_{\max }$ values for site-A (open bars) in $20 \mathrm{~d}$ membranes were determined from ${ }^{3} \mathrm{H}$-flunitrazepanI saluration binding; values for site-A at earlier ages $(7,10,12$, and $15 \mathrm{~d})$ were determined from 2 -site analysis of ${ }^{3} \mathrm{H}$-flunitrazepam competition curves, as described in Materials and Methods. Values for site-B (hatched bars) were determined from saturation binding of ${ }^{3} \mathrm{H}-\mathrm{Ro5}-4864$.

4864 could be used to characterize this site. Figure 6 shows that the binding of ${ }^{3} \mathrm{H}-\mathrm{Ro5}-4864$ to $7 \mathrm{~d}$ membranes was saturable and of high affinity $\left(K_{D}=41 \mathrm{~nm}\right)$. Interestingly, the number of binding sites was found to be similar in both early and late embryonic brain $\left(B_{\max }=2.7\right.$ and $2.5 \mathrm{pmol} / \mathrm{mg}$ protein in 7 and $20 \mathrm{~d}$ brain membranes, respectively).

To test the hypothesis that the ${ }^{3} \mathrm{H}-\mathrm{Ro} 5-4864$ binding site in embryonic chick brain corresponds to site-B (as determined by low-affinity binding of ${ }^{3} \mathrm{H}$-flunitrazepam), we tested various BZDs for their ability to compete for specific ${ }^{3} \mathrm{H}-\mathrm{R} 05-4864$ binding in $7 \mathrm{~d}$ brain. Figure 7 shows a representative experiment in which flurazepam was used as competitor. Flurazepam inhibited all of the specific binding with low affinity $\left(K_{I}\right.$ ca. 27 $\mu \mathrm{M}$; see Table 1), similar to the inhibition of the low-affinity component of ${ }^{3} \mathrm{H}$-flunitrazepam binding (Table 1, Fig. 3). Comparable results were obtained with all BZDs tested (Table 1). The close agreement between $K_{I}$ values for inhibition of ${ }^{3} \mathrm{H}$ $\mathrm{R} 05-4864$ binding and inhibition of ${ }^{3} \mathrm{H}$-flunitrazepam binding to site-B supports the contention that these 2 sites are identical.

As with the binding of ${ }^{3} \mathrm{H}$-flunitrazepam to site-B, ${ }^{3} \mathrm{H}-\mathrm{Ro} 5-$ 4864 binding displays a number of characteristics expected of a functional receptor. As shown in Figure 8, $\mathrm{B} 10(+)\left(K_{I}=0.36 \pm\right.$ $0.11 \mu \mathrm{M}, n=3$ ) was a more potent inhibitor of ${ }^{3} \mathrm{H}-\mathrm{R} 05-4864$ binding than $\mathrm{BlO}(-)\left(K_{I}=8.7 \pm 1.1 \mu \mathrm{M}\right)$. When membranes were heated $\left(100^{\circ} \mathrm{C}, 90 \mathrm{~min}\right)$, specific binding was reduced to $35 \%$ of control; binding was also sensitive to protease treatment (Table 2).

\section{Photoaffinity labeling of embryonic BZD binding sites}

I'o determine if a BZD receptor in embryonic brain homogenates could be photoaffinity-labeled by exposure to ultraviolet light in the presence of flunitrazepam, $20 \mathrm{~d}$ brain membranes were photolabeled with ${ }^{3} \mathrm{H}$-flunitrazepam and then subjected to SDS-PAGE. Radioactivity migrated as bands of $M, 48,000$ and 51,000 (Fig. 9), in good agreement with results obtained with adult rat brain (Battersby et al., 1979; Sieghart and Karobath, 1980; Thomas and Tallman, 1981). When $7 \mathrm{~d}$ membranes were photolabeled, a pattern similar to that obtained with $20 \mathrm{~d}$ membranes was observed (Fig. 9).

To determine if site-B could be photoaffinity-labeled, $7 \mathrm{~d}$ 
membranes were photoinactivated and clonazepam was tested for its ability to compete for ${ }^{3} \mathrm{H}$-flunitrazepam binding. The data in Figure 10 demonstrate that photoinactivation markedly reduced binding to site- $A$, whereas binding to site-B was unaffected, indicating that the latter is resistant to photoaffinity labeling. Thus, both labeled bands observed on SDS gels are associated with site-A.

\section{Developmental regulation of $B Z D$ binding sites}

Site-A increases in number approximately 5-fold between embryonic days 7 and 20 (see above). To better describe this change, we further examined ${ }^{3} \mathrm{H}$-flunitrazepam binding to brain membranes derived from 10,12, and $15 \mathrm{~d}$ embryos. As shown in Figure 11 (see legend for methods), the increase in the levels of site-A occurred gradually during embryonic development. Interestingly, during this same period, the number of site-B sites as determined by ${ }^{3} \mathrm{H}-\mathrm{Ro5}-4864$ binding remained constant.

\section{Discussion}

We previously identified 2 classes of BZD binding sites in the embryonic chick brain (Chan et al., 1983). In the present communication we characterize these sites further and describe their development during embryogenesis. High-affinity ${ }^{3} \mathrm{H}$-flunitrazepam binding sites (site-A) are present in the embryonic chick brain as early as embryonic day 5 (Hamburger and Hamilton stage 27 ) and increase approximately 5 -fold by embryonic day 20 (1 d prehatch). Because of the small size of the embryonic brain, we focused our studies on embryos that had developed for $7 \mathrm{~d}$ or more. A number of observations indicate that site-A is part of a functional BZD-GABA receptor complex. First, binding to site-A is potentiated by GABA (Table 3). Second, the relative affinities of a number of BZDs for binding to site-A correlate well with their relative potencies for potentiating GABA chemosensitivity in embryonic chick spinal cord cell cultures (Chan et al., 1983). Last, potentiation of GABA responses is inhibited by photoinactivation (Chan et al., 1983; Borden et al., 1984), as is binding to site-A (Fig. 10).

When 7 or 20 d embryonic brain membranes are photoaffinity-labeled with ${ }^{3} \mathrm{H}$-flunitrazepam and analyzed by SDS-PAGE, radioactivity is observed in 2 bands of apparent molecular weight 48,000 and 51,000 Da. The apparent resistance of site- $\mathrm{B}$ to photoinactivation (Fig. 10) argues that both labcled bands correspond to site-A. The similar pattern obtained at early and late developmental stages indicates that neither the molecular weights nor relative amounts of these receptor subunit proteins change appreciably during embryogenesis. It will be interesting to determine if the photolabeling pattern changes postnatally, as has been observed in the rat (Sieghart and Mayer, 1982; Eichinger and Sieghart, 1986).

Interestingly, GABA enhanced ${ }^{3} \mathrm{H}$-flunitrazepam binding at all stages examined, indicating that site- $A$ and $G A B A$ receptors are coupled early in development (by day 7). The enhancement by GABA of BZD binding is a good indicator of the ability of BZDs to potentiate GABA-induced conductance increases (Chan and Farb, 1985). Thus, it seems likely that functional BZD receptors are already present at the time when cell cultures are prepared from the embryonic chick CNS (Chan et al., 1983; Borden et al., 1984). This finding is consistent with the ability of GABA and BZDs to inhibit the spontaneous motility of $4 \mathrm{~d}$ embryos (Reitzel et al., 1979; Maderdrut et al., 1983), and also with biochemical studies suggesting that binding sites for BZDs and those for GABA reside on the same protein (Sigel and Barnard, 1984; Schoch et al., 1985). The precocious development of a functional BZD receptor suggests that modulation of neural activity may be important during early development of the chick CNS. It is interesting that BZD binding sites in the rat brain are first detected on gestational day 14 (Schlumpf et al., 1983). This dramatic difference in the rate of development of the BZD-GABA receptor complex may be another example of rapid embryonic maturation in avians compared with fetal development in mammals; alternatively, it may represent a fundamental difference in the functional role of neuromodulation in avian and mammalian development.

In contrast to the results obtained with $20 \mathrm{~d}$ membranes, competition curves employing membranes from younger embryos were "flattened," inconsistent with Michaelis-Menten binding to a single site. The results suggest the existence of a high-affinity component (site-A) and a second site of considerably lower affinity (site-B). The identification of low-affinity binding is dependent on the use of a high concentration of competitor to define nonspecific binding. In this investigation, $1 \mathrm{~mm}$ flurazepam was employed because of its high affinity and its high solubility in aqueous buffers. Importantly, despite its low affinity, ${ }^{3} \mathrm{H}$-flunitrazepam dissociates slowly $\left(t_{1 / 2}=2 \mathrm{~min}\right)$ from site-B. Thus, little bound radioactivity is lost during the filtration and washing procedure (total time, ca. $10 \mathrm{sec}$ ).

Sitc-B displays characteristics expected of a receptor binding site, including stereospecific binding and sensitivity to inactivation by heat and trypsin. Interestingly, Ro5-4864 was found to bind with high affinity to site-B $\left(K_{I}\right.$ ca. $\left.40 \mathrm{~nm}\right)$. This finding prompted us to examine the binding of ${ }^{3} \mathrm{H}-\mathrm{Ro} 5-4864$ to embryonic brain membranes. The $K_{I}$ values for inhibition of ${ }^{3} \mathrm{H}$ Ro5-4864 binding by a variety of BZDs agree closely with their $K_{l}$ 's for inhibiting low-affinity binding of ${ }^{3} \mathrm{H}$-flunitrazepam, supporting the view that the 2 sites are identical. Saturation binding of ${ }^{3} \mathrm{H}$-Ro5-4864 demonstrated that the levels of site- $\mathrm{B}$ are similar in 7 and $20 \mathrm{~d}$ embryonic brain (ca. $2.5 \mathrm{pmol} / \mathrm{mg}$ protein). Low-affinity ${ }^{3} \mathrm{H}$-flunitrazepam binding is readily detected in $7 \mathrm{~d}$ but not in $20 \mathrm{~d}$ membranes, where it is masked by the larger number of high-affinity sites.

The high affinity of Ro5-4864 for site-B clearly distinguishes this site from site-A and suggests a similarity between site-B and the "peripheral" site previously identified in non-neural tissues (such as kidney) and, more recently, in mammalian brain. However, site-B and the peripheral site may be different: there is only a fair correlation between the affinities of a series of BZDs for binding to the 2 sites $(r=0.86$; see Table 1). A further distinction is that binding to site- $\mathrm{B}$ displays stereospecificity (Fig. 8), a property not shared by the peripheral site (Schoemaker et al., 1983). It is not known if site-B is the chick equivalent of the peripheral site or if it represents a distinct receptor.

The function(s) of high-affinity ${ }^{3} \mathrm{H}-\mathrm{R} 05-4864$ binding sites, such as site-B and the peripheral site, remains to be elucidated. Peripheral binding sites have been identified in the brains of a number of mammalian species, but it is not clear whether such sites mediate the behavioral effects of Ro5-4864 (for review, see Pellow and File, 1984). Interestingly, the levels and distribution of peripheral binding sites vary considerably among species. For example, the rat brain contains relatively few peripheral sites (205 fmol/mg protein: Schoemaker et al., 1983), and these appear to be restricted to the ependyma and choroid plexus (Anholt et al., 1985); in contrast, the cat contains high levels of peripheral 
sites (ca. $6 \mathrm{pmol} / \mathrm{mg}$ protein), and these are widely distributed throughout the brain (Benavides et al., 1984). High receptor numbers are also found in the guinea pig brain (Weissman et al., 1984). The significance of these results is not understood but they should be considered when interpreting behavioral studies.

The number of peripheral sites in the neonatal rat brain is the same as in the adult (Anholt et al., 1985), whereas GABAlinked high-affinity ${ }^{3} \mathrm{H}$-flunitrazepam binding sites increase approximately 10-fold between these stages (Regan et al., 1980). The present study demonstrates that the levels of site- $B$ in the chick brain are stable by embryonic day 7 , whereas site- $\mathrm{A}$ increases throughout embryonic development. These results indicate a further similarity between site-B and the peripheral site and suggest that ${ }^{3} \mathrm{H}-\mathrm{Ro5}-4864$ binding sites may be important during early stages of development.

The BZDs produce diverse effects in a number of non-neural tissues, and these effects do not appear to be mediated by GABAlinked, high-affinity BZD receptors. It has been suggested that peripheral sites mediate the ability of BZDs to inhibit the proliferation of thymoma cells (Wang et al., 1984) and to induce melanogenesis in melanoma cells (Matthew et al., 1981). In contrast, peripheral binding sites do not appear to mediate BZDinduced differentiation of erythroleukemia cells (Wang et al., 1984). Similarly, there is a poor correlation between the peripheral binding site and the potencies of various BZDs for inducing ornithine decarboxylase activity and inhibiting NGFmediated neurite outgrowth in PC12 cells (Morgan et al., 1985). Other actions of the BZDs - such as inhibition of protein turnover in skeletal muscle cell cultures (Bandman et al., 1978), alteration of skeletal muscle contractility (Khan and Edman, 1983), and inhibition of cell motility in fibroblast cultures (Nagele et al., 1983)-require micromolar concentrations of diazcpam, consistent with an involvement of site-B or another lowaffinity site. The function of site-B remains an interesting question. It will be of interest to determine whether site-B modulates the migration and/or proliferation of neurons and glial cells in the embryonic CNS.

In conclusion, we have demonstrated that 2 types of BZD binding sites are present in the developing chick CNS and that both appear early in embryogenesis. High-affinity ${ }^{3} \mathrm{H}$-flunitrazepam binding sites (site-A) are coupled to GABA receptors by embryonic day 7, and the number of sites per milligram of protein increases 5 -fold between embryonic days 7 and 20 . Site-B, which displays high affinity for ${ }^{3} \mathrm{H}-\mathrm{Ro} 5-4864$, differs from any previously identified binding site. The number of site-B sites in embryonic day 7 brain exceeds the number of site-A by $8.6-$ fold, and the levels of site-B do not change between 7 and 20 $\mathrm{d}$ of embryonic development. The function of site-B is unknown, but its predominance in young embryos (relative to site-A) suggests that it may play a role in the early embryonic CNS.

\section{References}

Anholt, R. R. H., E. B. De Souza, M. L. Oster-Granite, and S. H. Snyder (1985) Peripheral-type benzodiazepine receptors: Autoradiographic localization in whole-body sections of neonatal rats. J. Pharmacol. Exp. Ther. 233: 517-526.

Bandman, E., C. R. Walker, and R. C. Strohman (1978) Diazepam inhibits myoblast fusion and expression of muscle specific protein synthesis. Science 200: 559-561.

Battersby, M. K., J. G. Richards, and H. Möhler (1979) Benzodiaze- pine receptor: Photoaffinity labeling and localization. Eur. J. Pharmacol. 57: 277-278.

Beaumont, K., J. B. Moberly, and D. D. Fanestil (1984) Peripheraltype benzodiazepine binding sites in a renal epithelial cell line(MDCK). Eur. J. Pharmacol. 103: 185-188.

Benavides, J., H. E. Savaki, C. Malgouris, C. Laplace, M. Daniel, F. Begassat, M. Desban, A. Uzan, M. C. Dubroeucq, C. Renault, C. Gueremy, and G. Le Fur (1984) Autoradiographic localization of peripheral benzodiazepine binding sites in the cat brain with $\left[{ }^{3} \mathrm{H}\right] \mathrm{PK}$ 11195. Brain Res. Bull. 13: 69-77.

Borden, L. A., C. Czajkowski, C. Y. Chan, and D. H. Farb (1984) Benzodiazepine receptor synthesis and degradation by neurons in culture. Science 226: 857-860.

Braestrup, C., and R. F. Squires (1977) Specific benzodiazepine receptors in rat brain characterized by high-affinity $\left[{ }^{3} \mathrm{H}\right]$ diazepam binding. Proc. Natl. Acad. Sci. USA 74: 3805-3809.

Burden, S. (1977) Development of the neuromuscular junction in the chick embyro: The number, distribution, and stability of acetylcholine receptors. Dev. Biol. 57: 317-329.

Chan, C. Y., and D. H. Farb (1985) Modulation of neurotransmitter action: Control of the $\gamma$-aminobutyric acid response through the benzodiazepine receptor. J. Neurosci. 5: 2365-2373.

Chan, C. Y., T. T. Gibbs, L. A. Borden, and D. H. Farb (1983) Multiple embryonic benzodiazepine binding sites: Evidence for functionality. Life Sci. 33: 2061-2069.

Cheng, Y., and W. H. Prusoff (1973) Relationship between the inhibition constant $\left(\mathrm{K}_{1}\right)$ and the concentration of inhibitor which causes 50 per cent inhibition $\left(\mathrm{I}_{50}\right)$ of an enzymatic reaction. Biochem. Pharmacol. 23: 3099-3108.

Choi, D. W., D. H. Farb, and G. D. Fischbach (1977) Chlordiazepoxide selectively augments GABA action in spinal cord cell cultures. Nature 269: 342-344.

Choi, D. W., D. H. Farb, and G. D. Fischbach (1981) Chlordiazepoxide selectively potentiates GABA conductance of spinal cord and sensory neurons in cell culture. J. Neurophysiol. 45: 621-631.

Cochard, P., M. Goldstein, and I. B. Black (1978) Ontogenetic appearance and disappearance of tyrosine hydroxylase and catecholamines in the rat embryo. Proc. Natl. Acad. Sci. USA 75:2986-2990.

Costa, T., D. Rodbard, and C. B. Pert (1979) Is the benzodiazepine receptor coupled to a chloride anion channel? Nature 277: 315-317.

Eichinger, A., and W. Sieghart (1986) Postnatal development of proteins associated with different benzodiazepine receptors. J. Neurochem. 46: 173-180.

Enna, S. J., H. I. Yamamura, and S. H. Snyder (1976) Development of muscarinic cholinergic and GABA receptor binding in chick embryo brain. Brain Res. 101: 177-183.

Farb, D. H., L. A. Borden, C. Y. Chan, C. M. Czajkowski, T. T. Gibbs, and G. D. Schiller (1985) Modulation of neuronal function through benzodiazepine receptors: Biochemical and electrophysiological studies of neurons in primary monolayer cell culture. Ann. NY Acad. Sci. 43.5: $1-31$.

Gibbs, T. T., C. Y. Chan, C. M. Czajkowski, and D. H. Farb (1985) Benzodiazepine receptor photoaffinity labeling: Correlation of function with binding. Eur. J. Pharmacol. 110: 171-180.

Haefely, W., and P. Polc (1983) Anxiolytics: Neurochemical, Behavioral, and Clinical Perspectives, J. B. Malick, S. J. Enna, and H. I. Yamamura, eds., Raven, New York.

Hamburger, V., and H. L. Hamilton (1951) A series of normal stages in the development of the chick embryo. J. Morphol. 88: 49-92.

Hooke, R., and T. A. Jeeves (1961) 'Direct search' solution of numerical and statistical problems. J. Assoc. Comput. Mach. 8: 212229.

Khan, A. R., and K. A. P. Edman (1983) Diazepam, a highly effective twitch potentiator in isolated muscle fibers of the frog. Acta Physiol. Scand. 117: 533-539

Laemmli, U. K. (1970) Cleavage of structural proteins during the assembly of the head of bacteriophage T4. Nature 227:680-685.

Maderdrut, J. L., R. W. Oppenheim, and J. L. Reitzel (1983) Behavioral analysis of benzodiazepine-mediated inhibition in the early chick embryo. Brain Res. 289: 385-390.

Matthew, E., J. D. Laskin, E. A. Zimmerman, I. B. Weinstein, K. C. Hsu, and D. L. Engelhardt (1981) Benzodiazepines have high-affinity binding sites and induce melanogenesis in B16/C3 melanoma cells. Proc. Nati. Acad. Sci. USA 78: 3935-3939. 
Morgan, J. I., M. D. Johnson, J. K. T. Wang, K. H. Sonnenfeld, and S. Spector (1985) Peripheral-type benzodiazepines influence ornithine decarboxylase levels and neurite outgrowth in PC.12 cells. Proc. Natl. Acad. Sci. USA 82: 5223-5226.

Nagele, R. G., J. F. Pietrolungo, M. C. Kosciuk, H. Lee, and F. J. Roisen (1983) Diazcpam inhibits the spreading of chick embryo fibroblasts. Exp. Cell Res. 143: 153-162.

Pellow, S., and S. E. File (1984) Behavioural actions of Ro5-4864: A peripheral-type benzodiazepine? Life Sci. 35: 229-240.

Regan, J. W., W. R. Roeske, and H. I. Yamamura (1980) The benzodiazepine receptor: Its development and its modulation by $\gamma$-aminobutyric acid. J. Pharmacol. Exp. Ther. 212: 137-143.

Regan, J. W., H. I. Yamamura, S. Yamada, and W. R. Roeske (1981) High affinity renal $\left[{ }^{3} \mathrm{H} \mid\right.$ flunitrazepam binding: Characterization, localization, and alteration in hypertension. Life Sci. 28: 991-998.

Reitzel, J. L., J. L. Maderdrut, and R. W. Oppenheim (1979) Behavioral and biochemical analysis of GABA-mediated inhibition in the early chick embryo. Brain Res. 172: 487-504.

Schlumpf, M., J. G. Richards, W. Lichtensteiger, and H. Möhler (1983) An autoradiographic study of the prenatal development of benzodiazepine-binding sites in rat brain. J. Neurosci. 3: 1478-1487.

Schoch, P., J. G. Richards, P. Haring, B. Takacs, C. Stahli, T. Staehelin, W. Haefely, and H. Möhler (1985) Co-localization of $\mathrm{GABA}_{\mathrm{A}}$ receptors and benzodiazepine receptors in the brain shown by monoclonal antibodies. Nature 314: 168-171.

Schoemaker, H., R. G. Boles, W. D. Horst, and H. I. Yamamura (1983) Specific high-affinity binding sites for $\left[{ }^{3} \mathrm{H}\right] \mathrm{R} 05-4864$ in rat brain and kidney. J. Pharmacol. Exp. Ther. 225: 61-69.

Schuetze, S. M., E. F. Frank, and G. D. Fischbach (1978) Channel open time and metabolic stability of synaptic and extrasynaptic acetylcholine receptors on cultured chick myotubes. Proc. Natl. Acad. Sci. USA 81: 753-756.

Sher, P. K. (1985) Characteristics of benzodiazepine receptor binding in living cultures of mouse cerebral cortex at physiological temperature. Dev. Brain Res. 21: 133-136.

Sieghart, W., and M. Karobath (1980) Molecular heterogeneity of benzodiazepine receptors. Nature 286: 285-287.

Sieghart, W., and A. Mayer (1982) Postnatal development of proteins irreversibly labeled by $\left[{ }^{3} \mathrm{H}\right]$ flunitrazepam. Neurosci. Lett. $31: 71-74$.

Sigel, E., and E. A. Barnard (1984) A $\gamma$-aminobutyric acid/benzodiazepine receptor complex from bovine cerebral cortex. J. Biol. Chem. 259: 7219-7223.

Speth, R. C., G. J. Wastek, and H. I. Yamamura (1979) Benzodiazepine receptors: Temperature dependence of $\left[{ }^{3} \mathrm{H}\right]$ flunitrazepam binding. Life Sci. 24: 351-358.

Syapin, P. J., and P. Skolnick (1979) Characterization of benzodiazepine binding sites in cultured cells of neural origin. J. Neurochem. 32: 1047-1051.

Thomas, J. W., and J. F. Tallman (1981) Characterization of photoaffinity labeling of henzodiazepine hinding sites. J. Biol. Chem. 256: 9838-9842.

Walker, C. R., and J. H. Peacock (1981) Diazepam binding of dissociated hippocampal cultures from fetal mice. Dev. Brain Res. 1: 565578.

Wang, J. K. T., J. I. Morgan, and S. Spector. (1984) Benzodiazepines that bind at peripheral sites inhibit cell proliferation. Proc. Natl. Acad. Sci. USA 81: 753-756.

Weissman, B. A., G. T. Bolger, L. Isaac, S. M. Paul, and P. Skolnick (1984) Characterization of the binding of $\left[{ }^{3} \mathrm{H}\right] \mathrm{Ro5}-4864$, a convulsant benzodiazepine, to guinea pig brain. J. Neurochem. 42: 969975.

Wilson, B. W., M. A. Kaplan, W. C. Merhoff, and S. S. Mori (1970) Innervation and regulation of acetylcholinesterase activity during the development of normal and dystrophic chick muscle. J. Exp. Zool. 174: 39-54. 